\title{
Failure to Advance
}

National Cancer Institute

\section{Source}

National Cancer Institute. Failure to Advance. NCI Thesaurus. Code C63198.

Problem associated with failure to move the device to an intended location. 